\title{
紫外レーザーアブレーションによるカーボンナノチューブの生成
}

\author{
草場 光博，綱脇 惠章 \\ 大阪産業大学 工学部電気電子工学科 (广574-8530 大阪府大東市中垣内3-1-1)
}

\section{Formation of Carbon Nanotubes by Ultraviolet Laser Ablation}

\author{
Mitsuhiro KUSABA and Yoshiaki TSUNAWAKI
}

Department of Electrical Engineering and Electronics, Osaka Sangyo University, 3-1-1, Nakagaito, Daito, Osaka $574-8530$

(Received June 10,2004)

\begin{abstract}
Single-wall carbon nanotubes (SWNTs) were produced by an ablation method using a XeCl excimer laser. It was irradiated onto a graphite-Co/Ni target under the atmosphere $(0.1 \mathrm{MPa})$ of Ar gas with the flow rate of 12 $\mathrm{ml} / \mathrm{min}$ at the temperature of a room, $1273 \mathrm{~K}, 1373 \mathrm{~K}$, and $1473 \mathrm{~K}$. At the room temperature, the fiber-like deposition was observed on the target surface after the laser ablation. On the other hand, SWNTs were found in the carbonaceous soot produced by the laser ablation under the conditions of high temperature. The diameter distribution and the length of them were estimated to be between 1.2 and $1.7 \mathrm{~nm}$, and $2 \mu \mathrm{m}$ or above, respectively, by Raman spectroscopy and the scanning and transmission electron microscopy.
\end{abstract}

Key Words: Carbon nanotube, Single-wall carbon nanotube, Excimer laser, Laser ablation, Ultraviolet laser

1.はじめに

よく知られているように，グラファイトはグラフェン と呼ばれる炭素原子の平面状六員環ネットワークを1層と して，いくつものグラフェンが弱い力で結びついた多層 状構造をしている.カーボンナノチューブは，このグラ フェンが円筒状に巻かれた構造をしており，それが1層の ときは単層カーボンナノチューブ1)として，また多層の円 筒状グラフェンが入れ子になったときは多層カーボンナ ノチューブ2)として大別される。それらの直径は単層では $1 \mathrm{~nm}$ 程度, 多層では数 $10 \mathrm{~nm}$ 程度であり, 長さは共におよ そ1〜数 $10 \mu \mathrm{m}$ 程度で，ときにはそれ以上の長いものもあ る。単層カーボンナノチューブは, 電気的性質がグラ フェンの巻き方によって金属的または半導体的となる特 性をもっており，また極めて強勒な機械的性質やダイヤ モンドを超える熱伝導特性など優れた特徵を有してい る。これらの性質を利用して電界放出電子源, 走査型プ ローブ顕微鏡の探針や高強度複合材料などへの応用が期 待されており, 我々もカーボンナノチューブを用いた電 界放出型電子ビーム源の開発を行っている3,4). しかしな がら，実際にカーボンナノチューブを実用化するために は, 高純度で高品質なものを大量生産できることが必要 である. カーボンナノチューブは, 約 1473 K程度の高温条 件下で炭素クラスターを数 $\mathrm{ms}$ から数s間, 保持させること により得られる。また単層カーボンナノチューブを得る ためには，炭素源に触媒金属を添加する必要がある．現 在, カーボンナノチューブの合成法としてアーク放電
法, レーザーアブレーション法, 化学気相堆積 (CVD) 法 などが考案されており，それぞれの合成法には次のよう な長所短所がある。アーク放電法では，比較的結晶性の よい単層あるいは多層カーボンナノチューブが合成でき るが不純物が多く，レーザーアブレーション法では，高 純度で高品質のナノチューブを得ることができるが，大 量生産向きではない。また，CVD法は大量生産が可能で あるが，格子久陥の多いナノチューブが生成するなどで ある. 従って, 全ての用途に適用可能な合成方法は確立 されておらず，各用途に応じてこれらの合成法を使い分 けなければならないのが現状である。

レーザーアブレーション法は1995年にSmalleyらのグ ループによって開発された方法5)で, 現在までに高純度で 高品質な単層カーボンナノチューブを得る最適条件を求 めるために，ターゲット材料，雲囲気ガス圧力およびそ の流量, 合成温度やレーザー照射条件 (レーザーフルエン ス, パルス幅, 繰り返し周波数, 発振波長など)などをパ ラメータとした研究がなされている6-10). アブレーション 用レーザーとしては，Nd:YAGレーザー(発振波長：532 $\mathrm{nm}, 1064 \mathrm{~nm})$ や $\mathrm{CO}_{2}$ レーザー $(10.6 \mu \mathrm{m})$ のような可視から 赤外領域に発振波長をもつレーザーが一般に用いられて おり，紫外レーザーを用いた報告はほとんどない。紫外 レーザーは, 可視・赤外レーザーに比べて光子エネル ギーが高く，アブレーションによって生じたプルーム中 の原子や分子との相互作用が大きくなることから，新し い形状のカーボンナノ粒子および新たなナノチューブの 生成メカニズムの発見が期待される. Braidyら ${ }^{11)}$ は, $\mathrm{KrF}$ 
エキシマレーザー $(248 \mathrm{~nm})$ を用いて実験し, Nd:YAGレー ザーの場合に比べて比較的低温の $823 \mathrm{~K}$ から $1423 \mathrm{~K} て ゙$ 単層 カーボンナノチューブが生成することを見出したが，そ の生成メカニズムについての議論はなされていない。 我々は紫外レーザー照射によるカーボンナノチューブの 合成を試み，生成メカニズムについて詳細に調べ，新し いナノカーボン材料の創製への知見を得ること，および 合成したナノカーボン材料を用いた電子デバイスへ応用 することを目的として研究を進めている。

本論文では，紫外レーザーとして XeClエキシマレー ザー(308 nm)を用い，室温および $1273 \mathrm{~K}, 1373 \mathrm{~K}, 1473 \mathrm{~K}$ の高温下でカーボンナノチューブの合成を試みたとこ ろ，いずれの高温条件下でも直径 1.2 から $1.7 \mathrm{~nm}$ ，長さ2 $\mu \mathrm{m}$ 以上の単層カーボンナノチューブが生成し，室温では ターゲット表面に繊維状物質が生成することが分かった ので報告する。

\section{2. 単層カーボンナノチューブの合成}

XeClエキシマレーザー (Lambda Physik, COMPex102)を 光源としたカーボンナノチューブ合成装置図をFig. 1に示

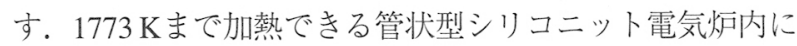
直径 $51 \mathrm{~mm}$ のセラミックチューブを挿入し，さらにその中 に直径 $38 \mathrm{~mm}$ の石英管を入れた2重構造にし，石英管の中 央には，それぞれ1.2原子量\%のCoと Niを含んだグラファ イトターゲットを設置した。石英管の両端にMo板を置 き，そこにアブレーションされた物質を堆積させた。 セ ラミックチューブの両端はステンレス製の合成石英空付 き水冷蓋で封じ，䨌囲気ガスの種類，流量，圧力および 炉温度などの合成条件は，従来のNd:YAGレーザーおよび $\mathrm{CO}_{2}$ レーザーを用いたアブレーション実験の場合と同様と した。すなわち，セラミックチューブ内を真空に引いた 後，Arガスを0.1 MPaの圧力にまで満たし， $12 \mathrm{ml} / \mathrm{min}$ の流 量でレーザー入射側から流した。合成温度依存性を調べ るために，炉温度を $1273 \mathrm{~K} ， 1373 \mathrm{~K} ， 1473 \mathrm{~K}$ およ゙室温 とした。 XeClエキシマレーザー(パルス幅：16ns, 繰り返 し周波数 $10 \mathrm{~Hz}$ ) 焦点距離 $60 \mathrm{~cm}$ の石英レンズでグラファ イトターゲット表面上に絞って，1時間照射した。その時 のターゲット表面でのレーザーパワー密度は，140 MW/ $\mathrm{cm}^{2}$ であった。アブレーション娞，ターゲット前方拈よび 後方のMo板上に煤状の物質が堆積するのを確認した。堆 積物のMo板上の位置および前方と後方のMo板上の堆積物 の割合は，照射レーザーパワー密度およびArガス流量に

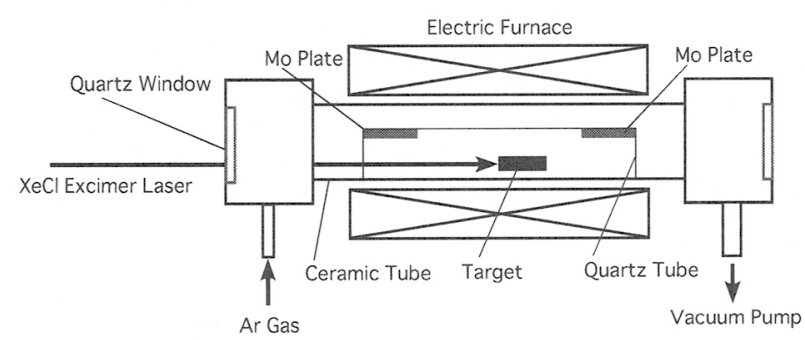

Fig. 1 Experimental set-up for the synthesis of carbon nanotubes by using a $\mathrm{XeCl}$ excimer laser.
大きく依存した。堆積物は走査型電子顕微鏡 $($ SEM) (日 立, S-4700) と透過型電子顕微鏡 (TEM) (日立, H 9000UHR)による観察，およびArイオンレーザー $(488 \mathrm{~nm}$ および514 nm) を励起光源とした顕微ラマン分光 (堀場, LabRamHR-800)測定をして評価した。

\section{3. 結果および考察}

合成温度 1273 Kでアブレーションしたときのターゲット 前方および後方に設置したMo板上の堆積物のSEM像をそ れぞれFig. 2(a), (b)に示す. 堆積物の中には, 長さ $2 \mu \mathrm{m}$ 以上のカーボンナノチューブと思われる瀻維状のものが 複雑に絡み合って存在し, その周囲には多数のアモル ファスカーボンおよび触媒金属微粒子 $(\mathrm{Ni}, \mathrm{Co})$ が付着し ているのが観測され，ターゲット前方および後方の堆積 物には，形態の違いがほとんど見られなかった. Fig. 3 (a)，(b)に1273 Kで合成された堆積物の低倍率(a)および 高倍率(b)のTEM像を示す. 直径数 $\mathrm{nm}$ 数 $10 \mathrm{~nm}$ の触媒金 属微粒子と直径約 $1.5 \mathrm{~nm}$ の単層カーボンナノチューブが絡 み合っており, 数本の束 (太さ：数 $10 \mathrm{~nm}$ ) を形成して存在 するのが見られる。また2層のものも極くわずかに存在す ることが分かった，3層以上のものについては，観察した 視野内においては確認されなかった。また，アモルファ スカーボンの粒径は， ～ $20 \mathrm{~nm}$ と観測され，今までに報告 されてきた可視・赤外のレーザーアブレーションによる 場合と比べて小さな值であった。他の高温下 $(1373 \mathrm{~K}$ と

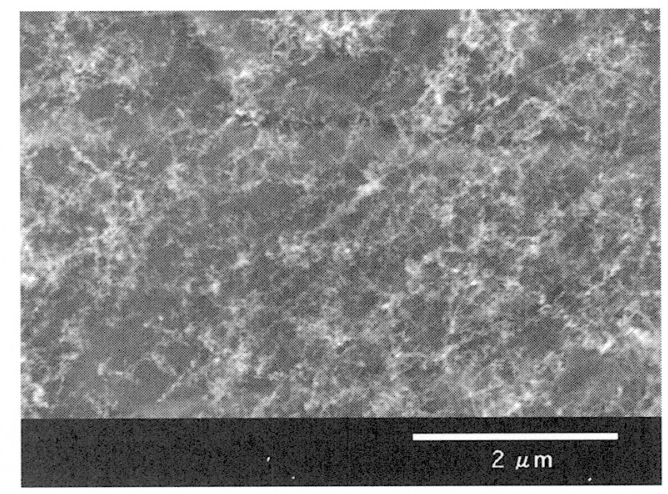

(a)

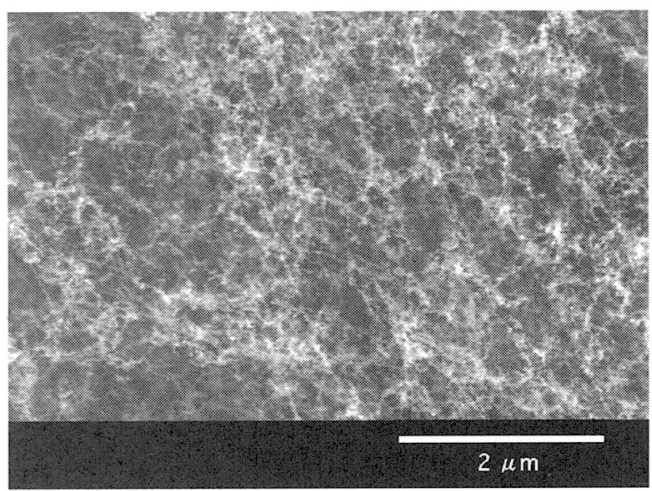

(b)

Fig.2 SEM images of the soot deposited on the Mo plate put (a) in front of and (b) behind the target after $\mathrm{XeCl}$ excimer laser ablation at $1273 \mathrm{~K}$. 


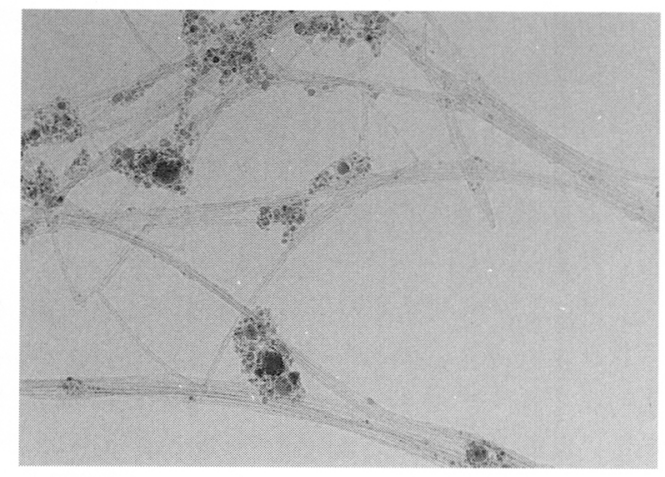

$100 \mathrm{~nm}$

(a)

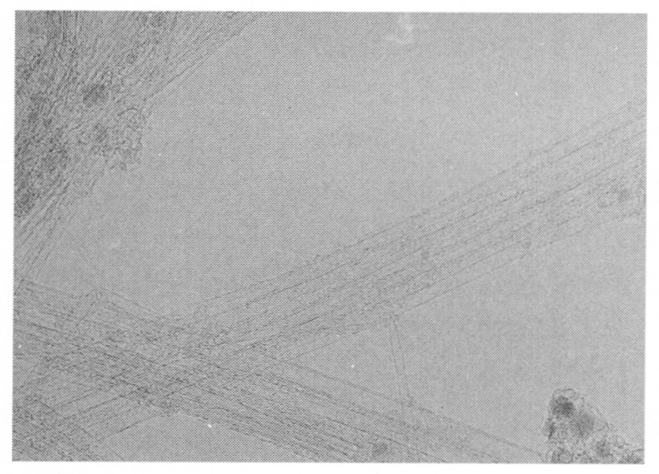

$20 \mathrm{~nm}$

(b)

Fig. 3 (a) Low and (b) high magnifications TEM images of the deposit produced by $\mathrm{XeCl}$ excimer laser ablation at $1273 \mathrm{~K}$.

1473 K ) で合成された堆積物においても，SEMおよびTEM 観察では，1273 Kにおける場合と同様，顕著な形態の変化 は見られなかった。

$1273 \mathrm{~K}, 1373 \mathrm{~K}$ おび $1473 \mathrm{~K} て ゙$ 合成された堆積物の高 波数領域および低波数領域のラマンスペクトル(励起波長 $514 \mathrm{~nm}$ ) 老Fig. 4(a)，(b)に示す. 高波数領域(Fig. 4(a))に は, $1590 \mathrm{~cm}^{-1}$ 付近に $\mathrm{G}$ バンドと呼ばれる炭素原子の六員環 ネットワーク内の格子振動に起因するピークと, $1335 \mathrm{~cm}^{-1}$ 付近に炭素の格子欠陥に起因するDバンドと呼ばれるピー ク12,13)が見られた。一般にGバンドとDバンドのピーク強 度比は, 単層カーボンナノチューブの純度の評価に利用 される。それらのピーク強度比は合成温度の増加ととも にわずかに増加した，しかし，可視・赤外レーザーでの 場合と比べ，Dバンドのピーク強度が高くなっている。こ れはFigs. 2，3の電子顕微鏡観察で見られたように，20 nm 程度の非常に細かいアモルファスカーボン微粒子の生成 により，この微粒子によるラマンピークが重なって現れ ているものと考えられる。従って，本研究におけるよう な場合, GバンドとDバンドのピーク強度比を比較するだ けでもって, 単層カーボンナノチューブの純度を評価す るのは不十分であり, 今後さらに検討していく必要があ る.

低波数領域においては，Fig. 4 (b)に見られるように， $180 \mathrm{~cm}^{-1}$ 付近を中心にして, いくつかのピークが観測され た.すなわち，温度の低い $1273 \mathrm{~K} て ゙ は ， 205 \mathrm{~cm}^{-1}$ 付近にも

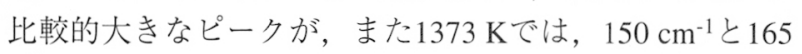

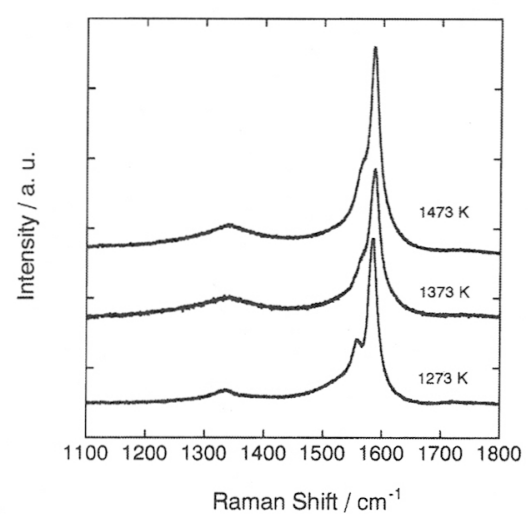

(a)

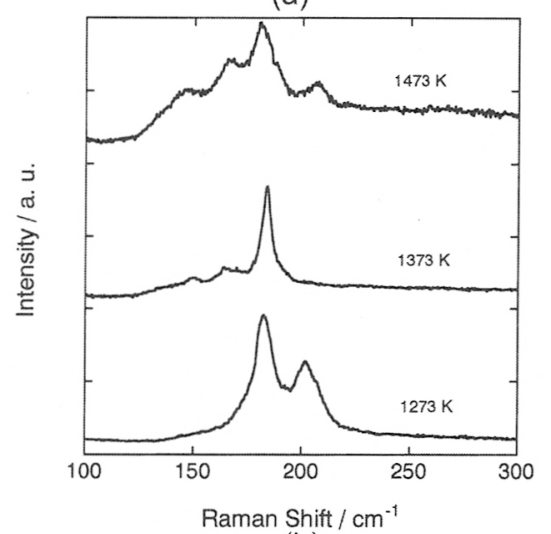

(b)

Fig. 4 Raman spectra of the deposit produced at 1273, 1373 and $1473 \mathrm{~K}$ in (a) high and (b) low frequency regions.

$\mathrm{cm}^{-1}$ 付近に弱いピークが現れた。 そして最も温度の高い

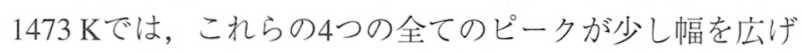
て現れるのが観測された。 これらのラマンピークは, 単 層カーボンナノチューブが半径方向へ伸縮振動すること によるラジアルブリージングモード (RBM $)^{12)}$ に基づいて おり, ラマンシフト $v\left(\mathrm{~cm}^{-1}\right)$ は, ナノチューブの直径 $d$ $(\mathrm{nm})$ との間に $v=248 / \mathrm{d}$ 関係があることが知られてい る13). 従って, 試料中には異なる直径をもつ単層カーボ ンナノチューブが混在していることが分かる。 ラマンス ペクトルの形状は試料の測定場所によって僅かに変化し たが，いずれの合成温度でもピークの波数は変化せず, 温度の増加とともに低波数のピークの強度が大きくな る。すなわち, 全体としてチューブ直径の平均值が大き くなることが分かった. 合成温度に対するチューブ直径 の関係はBandowらによって見出され14)，レーザーアブ レーションによって形成される炭素と触媒金属 (NiとCo) が混合したC-Ni-Co溶融粒子が雾囲気ガス温度にまで泠却 されて凝固する過程で, その冷却速度に依存してある大 きさをもつ $\mathrm{Ni}, \mathrm{Co} の$ 金属クラスターを形成し, 合成され るナノチューブの直径は, このクラスターサイズに依存 するとされている，従って雲囲気ガス温度が高いほど冷 却速度が遅くなり, より大きい触媒金属クラスターが形 成され，チューブ直径が大きくなると考えられる。本研 究で合成された単層カーボンナノチューブは, Fig. 3の TEM観察の結果とほほ一致して, 直径が $1.2 \mathrm{~nm}$ から $1.7 \mathrm{~nm}$ に分布していることが見出された。 
室温下におけるアブレーションでは, Mo板上には堆積 物が見出されなかった。 しかし, ターゲット表面に変化 が見られた. Fig. 5にアブレーション後のターゲット表面 のSEM観察結果を示す. Fig. 5 (a)に見られるようにアブ レーション部の周辺 $100 \mu \mathrm{m}$ 以内では，Nd:YAGレーザー照 射の場合 $\left.{ }^{15}\right)$ と同様, グラファイト抢よび触媒金属 $(\mathrm{Ni}$, Co）が溶融して固まった状態になっている。さらに数100

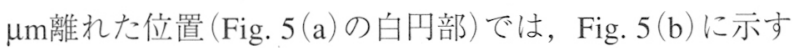
ように極く微量の繊維状の堆積物が観測された。このよ うに室温でのアブレーションによるターゲット表面での 繊維状の堆積物生成については, 今まで観測された報告 がなく，紫外レーザー特有の現象のように思われる。

グラファイトのレーザーアブレーションによる薄膜形 成のレーザー波長依存性はよく知られている16)、レー ザー波長が短くなるほど, ターゲットから放出されるク ラスター粒子の内部エネルギーがより高くなり, 従って 効率よくクラスター粒子の解離が進行するために粒子サ イズが小さくなる。その結果，より均質な薄膜が得られ る。カーボンナノチューブの場合，レーザー照射した直 後にターゲット表面から炭素原子 $\mathrm{C}$ や $\mathrm{C}_{2}, \mathrm{C}_{3}$ および触媒金 属などの微粒子が放出され, $\mathrm{CO}_{2}$ レーザーおよびNd:YAG レーザー (1064 nm) 照射の場合, プルーム診断の結 果 ${ }^{17,18)}, \mathrm{C}_{2}$ の速度はそれぞれ約 $10^{3} \mathrm{~cm} / \mathrm{s}$ と $10^{5} \mathrm{~cm} / \mathrm{s}$ と見積も られている。このような速度をもった微粒子は, $\mathrm{Ar}$ との 衝突を繰り返しながら減速・冷却されつつ, 炭素と金属 ( $\mathrm{Ni}$ と $\mathrm{Co})$ が混合したC-Ni-Co溶融粒子をそれぞれ2〜 $5 \mathrm{~ms}$ と約 $100 \mathrm{~ms}$ かって形成し, 雰囲気ガス温度にまで達す

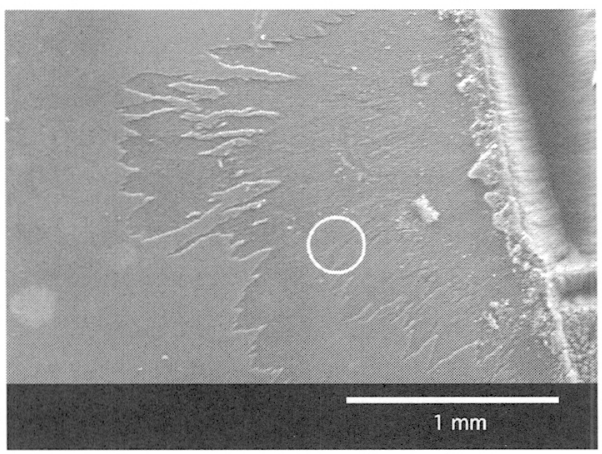

(a)

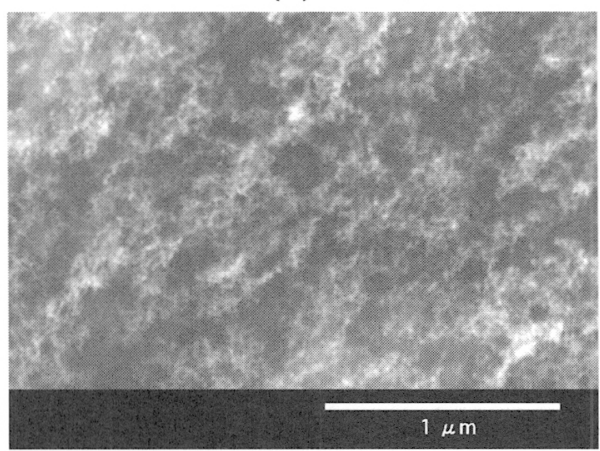

(b)

Fig. 5 SEM image of the target surface after $\mathrm{XeCl}$ excimer laser ablation at room temperature. (a) Low magnification and (b) higher magnification of the portion circled in the image (a).
る。この冷却の間にNiとCoの金属クラスターが形成さ れ，その触媒作用により，数msから数sの間にカーボンナ ノチューブへと成長するものと考号れている19)。この ように照射レーザーの波長が短い方がアブレーションさ れた粒子の運動エネルギーは高く, そして粒子の冷却速 度は遅くなる、 $\mathrm{XeCl}$ エキシマレーザーの場合, グラファ イトターゲットから放出される $\mathrm{C}_{2}$ の速度は, $10^{6} \mathrm{~cm} / \mathrm{s}$ 程度 と評価されており20), 可視・赤外レーザーに比べてより 高い運動エネルギーをもった微粒子が放出される。従っ てより長い時間にわたってArとの衝突を繰り返し，より 高エネルギーのC-Ni-Co溶融粒子が形成され, Braidyらの 結果 ${ }^{11)}$ に見られたように, 比較的低温でも単層カーボン ナノチューブが生成し，また本研究に扔けるようなナノ チューブの生成と同時に形成されるアモルファスカーボ ンは，その粒子サイズが非常に小さく（２２ｎｍ）なったも のと思われる。また室温下でのアブレーションにおいて も, 紫外レーザーの高い光子エネルギーにより, ター ゲット表面で高温のC-Ni-Co溶融粒子が生じ, 室温になる までの間に繊維状堆積物へ成長したものと考えられる. なお，この高エネルギー微粒子とカーボンナノチューブ の成長メカニズムとの詳細な関係については, さらにプ ルーム診断などをすることによって明らかになるであろ う.

\section{4. まとめ}

レーザーアブレーションによるカーボンナノチューブ の合成には，主に可視・赤外レーザーが従来から用いら れてきた。本研究では, さらに波長の短い紫外レー ザー, すなわち $\mathrm{XeCl}$ エシシマレーザーを用いてカーボン ナノチューブの合成を試み，走査型および透過型電子顕 微鏡観察とラマン分光測定をして生成物の評価をした。 実験は可視・赤外レーザーを用いて報告されてきたのと ほほ同じ条件下で行った。その結果, $1273 \mathrm{~K}, 1373 \mathrm{~K}$, $1473 \mathrm{~K}$ の高温下では, 直径 $1.2 \mathrm{~nm}$ から $1.7 \mathrm{~nm}$, 長さ $2 \mu \mathrm{m}$ 以 上の単層カーボンナノチューブが生成し, その平均の チューブ直径が合成温度の増加とともにわずかに大きく なることが，また生成されるアモルファスカーボンの大 きさが非常に小さくなることが分かった。 さらに室温下 でも，ターゲット表面に繊維状の堆積物が観測された。 紫外レーザーは光子エネルギーが高く，従ってターゲッ トからは可視・赤外レーザー照射の場合よりも高い運動 エネルギーをもった炭素 $\mathrm{C} や \mathrm{C}_{2}, \mathrm{C}_{3}$ や金属などの微粒子が 放出され，より高温なC-Ni-Co溶融粒子が形成され，それ が雲囲気ガス温度に冷却されるまでに単層カーボンナノ チューブが生成したものと考えられる。今後, 紫外レー ザーに対するカーボンナノチューブ生成の最適条件を見 出し，またそのレーザー波長依存性も調べ，カーボンナ ノチューブの生成過程の知見を得，その応用を試みたい と考えている. 
謝 辞

本研究は大阪大学レーザー核融合研究センター(現, レーザーエネルギー学研究センター) との共同研究の一部 として実施された。また本研究の一部は，文部科学省科 学研究費 (基盤研究 $(\mathrm{B}))$ )の補助を受けた。

\section{参考文献}

1) S. Iijima and T. Ichihara: Nature 363 (1993) 603.

2) S. Iijima: Nature 354 (1991) 56.

3) Y. Tokura, Y. Tsunawaki, N. Ohigashi, S. Akita, Y. Nakayama, K. Imasaki, K. Mima, and S. Nakai: Nucl. Instr. and Meth. A475 (2001) 458.

4) Y. Tsunawaki, M. Masuda, Y. Tokura, M. Kusaba, N. Ohigashi, S. Akita, Y. Nakayama, M. Asakawa, K. Imasaki, and K. Mima: Proc. 23rd Int. Free Electron Laser Cof., Darmstadt, Germany, 2002 p. II-47.

5) T. Guo, P. Nikolaev, A. Thess, D. T. Colbert, and R. E. Smalley: Chem. Phys. Lett. 243 (1995) 49.

6) M. Zhang, M. Yudasaka, and S. Iijima: Chem. Phys. Lett. 336 (2001) 196.

7) M. Yudasaka, T. Ichihashi, and S. Iijima: J. Phys. Chem. B 102 (1998) 10201

8) A. A. Gorbunov, R. Friedlein, O. Jost, M. S. Golden, J. Fink, and
W. Pompe: Appl. Phys. A 69 (1999) S593.

9) D. Nishide, H. Kataura, S. Suzuki, K. Tsukagoshi, Y. Aoyagi, and Y. Achiba: Chem. Phys. Lett. 372 (2003) 45.

10) W. K. Maser, A. M. Benito, and M. T. Martinez: Carbon 40 (2002) 1685.

11) N. Braidy, M. A. El Khakani, and G. A. Botton: Chem. Phys. Lett. 354 (2002) 88.

12) A. M. Rao, E. Richter, S. Bandow, B. Chase, P. C. Eklund, K. A. Williams, S. Fang, K. R. Subbaswamy, M. Menon, A. Thess, R. E. Smalley, G. Dresselhaus, and M. S. Dresselhaus: Science 275 (1997) 187.

13) A. Jorio, R. Saito, J. H. Hafner, C. M. Lieber, M. Hunter, T. McClure, G. Dresselhaus, and M. S. Dresselhaus: Phys. Rev. Lett. 86 (2001) 1118

14) S. Bandow, S. Asaka, Y. Saito, A. M. Rao, L. Grigorian, E. Richter, and P. C. Eklund: Phys. Rev. Lett. 80 (1998) 3779.

15) M. Yudasaka, F. Kokai, K. Takahashi, R. Yamada, N. Sensui, T. Ichihashi, and S. Iijima: J. Phys. Chem. B 103 (1999) 3576.

16）英 貢, 大越昌幸：レーザー研究 26 (1998) 806.

17) F. Kokai, K. Takahashi, M. Yudasaka, R. Yamada, T. Ichihashi, and S. Iijima: J. Phys. Chem. B 103 (1999) 4346.

18) F. Kokai, K. Takahashi, K. Shimizu, M. Yudasaka, and S. Iijima: Appl. Phys. A 69 (1999) S223.

19）小海文夫，高橋邦充，湯田坂 雅子，飯島澄男：レーザー研 究 28 (2000) 342.

20) J. Hermann, C. Vivien, A. P. Carricato, and C. Boulmer-Leborgne: Appl. Surf. Sci. 127-129 (1998) 645 